\title{
EVALUATION OF ASSESSMENTS IN SUPERVISION OVER THE TERRITORIAL SELF-GOVERNMENT NAD SAMORZĄDEM TERYTORIALNYM
}

\begin{abstract}
Supervision in the light of administrative law and doctrine means a specific, law-based function aimed at ensuring proper operation of specific elements of the public administration system by the legally authorized entities, having appropriate competence to check and to evaluate such activity according to the adopted assessment criteria. The annulment of local law acts enacted by the commune authorities, the dismissal of the executive body and the suspension of commune bodies as well as the establishment of a receivership are the basic means of supervision over the activities of municipalities

The supervisory authorities, within the framework of exercising supervision over territorial self-government, determine discrepancies between the actual state and the postulated state. Based on these findings, the evaluations are made which are subject to a particular valuation. Depending on the result of this evaluation, the supervisory authority decides on the implementation of a particular supervisory measure. An important element of the supervisory proceedings is the evaluation of assessments, because not every activity assessed as incorrect or unlawful results in the obligation to apply a supervision measure.

The purpose of this article is to present legal and organizational aspects of the evaluation of assessments as part of the supervision of local government, resulting in the implementation of selected supervisory measures such as: the annulment of a local law and suspension of local government bodies.
\end{abstract}




\section{STRESZCZENIE}

Nadzór w świetle prawa administracyjnego i doktryny oznacza swoistą, opartą na prawie funkcję, mającą zapewnić prawidłowe działanie określonych elementów systemu administracji publicznej przez umocowane prawnie podmioty, posiadające stosowne kompetencje do sprawdzania i oceny takiej działalności według przyjętych kryteriów ocen. Do podstawowych środków nadzoru nad działalnością gmin zalicza się stwierdzenie nieważności aktów prawa miejscowego stanowionych przez organy gminy, odwołanie organu wykonawczego oraz zawieszenie organów gminy i ustanowienie zarządu komisarycznego.

Organy nadzoru w ramach sprawowania nadzoru nad samorządem terytorialnym ustalają rozbieżności pomiędzy stanem faktycznym a stanem postulowanym. Na podstawie tych ustaleń formułowane są oceny, które poddane są określonemu wartościowaniu. W zależności od wyniku tego wartościowania organ nadzoru podejmuje decyzje o zastosowaniu danego środka nadzorczego. Istotnym elementem postępowania nadzorczego jest zatem wartościowanie ocen, albowiem nie każda działalność oceniona jako nieprawidłowa, czy też niezgodna z prawem, skutkuje obowiązkiem zastosowania środka nadzoru.

Celem niniejszego artykułu jest przedstawienie prawnych i organizacyjnych aspektów wartościowania ocen w ramach nadzoru nad samorządem terytorialnym, skutkująca zastosowaniem wybranych środków nadzorczych, tj. stwierdzeniem nieważności aktu prawa miejscowego oraz zawieszeniem organów jednostki samorządu terytorialnego.

KEYWORDS: supervision, evaluation, municipality, assessment, local government

SŁOWA KLUCZOWE: nadzór, wartościowanie, gmina, oceny, samorząd terytorialny

\section{WPROWADZENIE}

Nadzór w świetle prawa administracyjnego i doktryny oznacza swoistą, opartą na prawie funkcję mającą zapewnić prawidłowe działanie określonych elementów systemu administracji publicznej przez umocowane prawnie podmioty, posiadające stosowne kompetencje do sprawdzania i ocenę takiej działalności według przyjętych kryteriów ocen. Cechą charakterystyczną nadzoru jest sprawdzanie i ocenianie działalności podmiotów nadzorowanych, a także możliwość władczej ingerencji w działalność takich podmiotów. Nadzór w administracji publicznej należy rozpatrywać przede wszystkim w aspekcie struktur administracyjnych, wzajemnie powiązanych poprzez stosowne regulacje ustrojowe i organizacyjne. Nadzór ma szczególne znacze- 
nie w przypadku struktur zdecentralizowanych, takich jak samorząd terytorialny. Pełni w nich funkcję stabilizującą proces realizacji zadań publicznych, a także zapewnienia łączności pomiędzy poszczególnymi elementami struktury zarówno w skali makro, tj. w ramach całego aparatu administracji, jak i na poziomie poszczególnych jednostek samorządu terytorialnego. Nadzór niewątpliwie ogranicza samodzielność i swobodę działania jednostek samorządu terytorialnego, dlatego jego zakres, kryteria oraz organy są unormowane w Konstytucji (Wiktorowska, 2002, s. 193).

W systemie prawno-ustrojowym Polski działalność jednostek samorządu terytorialnego podlega nadzorowi z punktu widzenia legalności, zgodnie z art. 171 ust. 1 Konstytucji RP. Nadzór nad działalnością samorządu terytorialnego sprawuje Prezes Rady Ministrów i wojewoda, a w zakresie spraw finansowych - regionalne izby obrachunkowe. Uprawnienia nadzorcze zostały również przypisane Sejmowi, który może rozwiązać organ stanowiący gminy w przypadku powtarzającego się naruszenia Konstytucji lub ustaw (Stahl, 2002, s. 338). Szczegółowy zakres, kryteria oraz środki nadzoru uregulowane są natomiast odpowiednio w ustawie o samorządzie gminnym, ustawie o samorządzie powiatowym i ustawie o samorządzie województwa, a także ustawie o regionalnych izbach obrachunkowych oraz ustawie o wojewodzie i administracji rządowej w województwie. Jak trafnie zauważa B. Sitek, nie jest to nadzór „nieograniczony”, ponieważ w Polsce występuje duży stopień decentralizacji i kontrola nie może ograniczać autonomii samorządu (Sitek, 2016, s. 137-138).

Zagadnienie wartościowania ocen w ramach wybranych środków nadzoru zostanie przedstawione w niniejszym artykule na przykładzie nadzoru nad samorządem gminnym.

\section{KRYTERIA I ZASIĘG NADZORU NAD SAMORZĄDEM TERYTORIALNYM}

Przepisy ustawy o samorządzie gminnym określają, że nadzór nad działalnością gminną sprawowany jest na podstawie kryterium zgodności z prawem (art. 85 ustawy o samorządzie gminnym). Legalność działania administracji definiuje się jako zgodność działania zarówno z ustawami, jak i aktami wykonawczymi, aktami wewnętrznymi oraz umowami, decyzjami i innymi rozstrzygnięciami (Stahl, 2002, s. 338). Organy nadzoru mogą jednak 
wkraczać w działalność gminną tylko w przypadkach określonych ustawami (art. 87). W doktrynie i orzecznictwie przyjmuje się bowiem, że ocena zgodności z „prawem” jest pojęciem szerszym niż pojęcie „ustawa”, przy czym w przypadku ingerencji w działalność samorządu terytorialnego niedopuszczalna jest wykładnia rozszerzająca. Dlatego stosując środek nadzoru, należy zawsze przywołać konkretny przepis ustawy ub równorzędnego aktu, który został naruszony. Przesłanką stosowania środka nadzoru nie może być natomiast jedynie akt wykonawczy (Dolnicki, 2009, s. 415; Chmielnicki, 2004, s. 568). Unormowanie w Konstytucji i ustawach instytucji nadzoru nad samorządem terytorialnym odpowiada przy tym wymogom art. 8 ust 1 Europejskiej Karty Samorządu Terytorialnego. W art. 8 EKST użyto wprawdzie pojęcia kontroli administracyjnej, niemniej pojęcie to należy odnosić przede wszystkim do nadzoru nad samorządem terytorialnym.

Należy zaznaczyć, że EKST stanowi istotny wyznacznik sposobu uregulowania kryteriów i zasięgu nadzoru nad działalnością samorządu terytorialnego. EKST w art. 8 ust. 2 (zdanie pierwsze) przewiduje bowiem, że „Wszelka kontrola administracyjna działalności społeczności lokalnych powinna w zasadzie mieć na celu jedynie zapewnienie przestrzegania prawa i zasad konstytucyjnych. Kontrola administracyjna może jednakże obejmować kontrolę celowości realizowaną przez organ wyższego szczebla w odniesieniu do zadań, których wykonanie zostało społecznościom lokalnym delegowane. Z treści art. 8 EKST wynika wprawdzie, że nadzór nad realizacją zadań zleconych mógłby być sprawowany zarówno według kryterium legalności, jak i celowości, niemniej treść art. 171 Konstytucji jednoznacznie wskazuje, że jedyną przesłanką ingerencji organów nadzoru w działalność samorządu terytorialnego może być naruszenie przez organy tego samorządu obowiązujących przepisów prawa. Zasięg i rodzaj stosowanych środków nadzoru powinien być przy tym proporcjonalny do znaczenia interesów, które ma on chronić, stosownie do art. 8 ust. 3 EKST.

\section{KRYTERIA NADZORU A WARTOŚCIOWANIE OCEN}

Jednym z głównych czynników zapewniających przestrzeganie zasady proporcjonalności środków nadzoru w stosunku do rodzaju i stopnia nieprawidłowości w działaniach organów gminy są ustawowe regulacje wartościujące oceny 
według kryterium legalności. Ustawa o samorządzie gminnym wartościuje takie oceny i w zależności od stopnia naruszenia prawa lub rodzaju nieprawidłowości przewiduje możliwość zastosowania określonego w środkach nadzoru.

Wartościowanie ocen formułowanych wg kryterium legalności polega na przykład na rozróżnieniu istotnej oraz nieistotnej sprzeczności z prawem aktów prawa miejscowego podlegające nadzorowi ze strony wojewody. Jak trafnie zauważa M. Kamiński, sprzeczność z prawem jest „kwalifikowanym rodzajem niezgodności, który powoduje, że dwie normy o tożsamych hipotezach wykluczają się bezpośrednio i bezwzględnie w zakresie dyspozycji”. Istotną sprzeczność ww. autor zdefiniował jako naruszenie przepisów ustrojowych określających organizację i działanie organów, naruszenie przepisów proceduralnych, regulujących tryb wydawania aktów oraz norm kompetencyjnych, w tym granice przedmiotowe i podmiotowe do wydania aktu oraz prawną formę działania. Za nieistotne $\mathrm{w}$ doktrynie uznaje się natomiast naruszenie przepisów materialnych niewpływających na treść aktu oraz innych przepisów niezwiązanych z formą i treścią aktów np. przepisy dotyczące redagowania aktów prawnych (Kamiński, 2011, s. 45).

Kolejnym przykładem wartościowania ocen działania gminy według kryterium legalności jest rozróżnienie „naruszenie prawa” oraz „powtarzające się naruszenie Konstytucji i ustaw”. Konsekwencją naruszenia prawa przez organy gminy w zależności od konkretnego przypadku może być wyeliminowaniem z porządku prawnego danego aktu normatywnego lub decyzji administracyjnej, wydanie przez wojewodę zarządzenia zastępczego (w ściśle określonych prawem sytuacjach), czy też zobowiązanie przez sąd do wykonania czynności (w razie bezczynności lub przewlekłości działania). Dopiero powtarzające się naruszenie (...) Konstytucji lub ustaw" będzie mogło skutkować zastosowaniem wobec organów gminy środka nadzorczego w postaci odwołania organu wykonawczego.

Ustawodawca w odmienny sposób uregulował natomiast wartościowanie ocen stanowiących podstawę zawieszenia w ramach nadzoru organów gminy ze względu na nieprawidłową realizację zadań publicznych. W ustawach samorządowych brak jest bowiem literalnego odwołania do kryterium zgodności z prawem. Wskazana jest natomiast przesłanka przedłużającego się i nierokującego nadziei braku skuteczności w realizacji zadań. Przepisy odsyłają zatem do zasad prakseologicznych przy ocenie prawidłowości reali- 
zacji określonych prawem zadań publicznych. Ze względu na organizacyjny charakter zadań publicznych jest trafne rozwiązanie i uwzględnia postulaty i poglądy doktryny w tej kwestii.

Powyższe uwagi i poglądy dotyczące ocen działalności organów gminy według kryterium legalności i potencjalnych skutków naruszenia prawa uzasadnia twierdzenie, że tylko działalność oceniona jako kwalifikowane naruszenie prawa w zakresie odpowiedniego stanowienia ze względu na istotność, lub stosowania prawa czy też powtarzalność albo trwały brak skuteczności w realizacji zadań, uprawnia organy nadzoru do stosowania środków ograniczających samodzielność jednostki samorządu terytorialnego.

\section{USTALANIE STANU FAKTYCZNEGO W PROCESIE WARTOŚCIOWANIA OCEN}

Formułowanie i wartościowanie ocen przez organ nadzoru wymaga uprzedniego ustalenia stanu faktycznego. W celu realizacji uprawnień nadzorczych wobec gmin organy nadzoru (Prezes Rady Ministrów, wojewodowie oraz regionalne izby obrachunkowe w sprawach finansowych) zostały wyposażone w niezbędne kompetencje umożliwiające ustalenie faktów niezbędnych do sformułowania prawidłowych ocen działalności i w konsekwencji zastosowania środków nadzorczych. Organy nadzoru, zgodnie z art. 88 ustawy o samorządzie gminnym, mają prawo żądania informacji i danych, dotyczących organizacji i funkcjonowania gminy. Powyższe uprawnienia zostały uregulowane bardzo ogólnie, w porównaniu np. z normami określającymi uprawnienia organów kontroli w zakresie ustalania stanu faktycznego. Przepisy nie określają chociażby formy, w jakiej organ nadzoru powinien udokumentować ustalenia, a także katalogu dowodów (oprócz żądania informacji i danych), które organ nadzoru może przeprowadzić przed zastosowaniem określonego środka nadzorczego, na przykład przesłuchanie w charakterze świadka. Uregulowanie w sposób ogólny kompetencji w zakresie ustalania stanu faktycznego jest zazwyczaj korzystne dla organu nadzoru, ponieważ pozwala „swobodnie” prowadzić czynności sprawdzające i kontrolne, na podstawie których organ nadzoru podejmie decyzje o konieczności zastosowania środka nadzoru. Z drugiej strony 
może prowadzić do nadmiernej ingerencji w bieżące funkcjonowanie gminy poprzez na przykład obciążanie gmin obowiązkiem dostarczania organom nadzoru danych i informacji w zakresie nieadekwatnym do rodzaju i skali naruszeń prawa.

\section{WARTOŚCIOWANIE OCEN PRZY STOSOWANIU WYBRANYCH ŚRODKÓW NADZORU}

Do podstawowych środków nadzoru nad działalnością jednostek samorządu terytorialnego, w ramach którego organy nadzoru przeprowadzają stosowne wartościowanie ocen, to stwierdzenie nieważności aktów prawa miejscowego stanowionych przez organy jednostek samorządu terytorialnego, odwołanie organu wykonawczego oraz zawieszenie organów JST i ustanowienie zarządu komisarycznego.

Stwierdzanie nieważności uchwał organów stanowiących oraz zarządzeń organu wykonawczego (wójta, burmistrza, prezydenta), ze względu na ich sprzeczność z prawem, jest najczęściej stosowanym środkiem nadzoru nad działalnością gmin. Stosowany jest zarówno wobec uchwał stanowionych przez rady gminy, jak i wobec zarządzeń organu wykonawczego. Ocenie podlegają zarówno przepisy miejscowe stanowione przez te organy, jak i sam proces ich tworzenia (Bułajewski, 2013, s. 99-101). Poddany ocenie akt musi jednak naruszać przepisy prawa w sposób „istotny”. O nieważności uchwały lub zarządzenia w całości, lub w części orzeka organ nadzoru (wojewoda lub regionalna izba obrachunkowa w przypadku uchwał podjętych w sprawach finansowych) w terminie nie dłuższym niż 30 dni od dnia doręczenia uchwały lub zarządzenia (Sitek, 2017, s. 154). Organ nadzoru stwierdza nieważność w formie aktów administracyjnych (rozstrzygnięć nadzorczych), do których zastosowanie mają odpowiednio przepisy ustawy - Kodeks postępowania administracyjnego. Wartościowanie ocen będzie w tym przypadku polegało na ustaleniu stopnia naruszenia prawa w procesie tworzenia aktów prawa miejscowego i stwierdzeniu ich nieważności, jeżeli naruszenie prawa zostanie ocenione jako istotne.

Do wartościowania ocen dochodzi również w przypadku stosowania środka nadzoru w postaci zawieszenia organów gminy. Jest to szczególny, personalny środek nadzoru, stosowany w sytuacji braku metodologicznej i rzeczywistej sprawności organów gminy. Zawieszenie organów gminy przez 
Prezesa Rady Ministrów i ustanowienie zarządu komisarycznego pozbawia czasowo możliwości sprawowania władzy przez organy gminy wybrane w wyborach powszechnych przez społeczność lokalną. Zaliczany jest również do „nadzwyczajnych” środków, ponieważ oddziałuje na konstytucyjnie i sądownie gwarantowaną samodzielność działania samorządu terytorialnego (Wiktorowska, 2002, s. 215-216). Środek nadzorczy w postaci zawieszenia organów gminy, zgodnie z art. 97 ust. 1 ustawy o samorządzie gminnym, może zostać zastosowany w przypadku przedłużającego się braku skuteczności w wykonywaniu ustawowo przekazanych gminie zadań publicznych oraz braku nadziei na poprawę takiego stanu. Należy zaznaczyć, że przesłanki zawieszenia, wymienione w powyższym przepisie, są przykładem odesłań do zasad prakseologicznych w prawie administracyjnym (Supernat, 1985, s. 318-320). Prakseologiczny charakter przesłanek zawieszenia nie oznacza, że ustawodawca niestosowania kryterium legalności w kontekście warunków zastosowania ww. środka nadzorczego. Jedynym kryterium nadzoru nad działalnością samorządu jest bowiem kryterium legalności, stosownie do art. 171 ust. 1 Konstytucji RP. Stwierdzenie braku skuteczności w realizacji zadań publicznych zawsze musi uwzględniać aspekt zgodności działania na podstawie i w granicach prawa, tj. ustalona w wyniku działalności wadliwa działalność organów gminy musi jednocześnie naruszać przepisy regulujące formę i sposób realizacji zadań publicznych. Powyższe stanowisko potwierdza m.in. Naczelny Sąd Administracyjny, który stwierdził, że „niewykonywanie ustawowo przekazanych jednostce samorządu terytorialnego zadań publicznych oznacza naruszenie podstawowych, ustawowych obowiązków władzy samorządowej. Organy władzy publicznej, jakimi są organy jednostek samorządu terytorialnego, działają na podstawie i w granicach prawa i wykonywanie zadań publicznych jest ich obowiązkiem, a nie prawem. Przedłużający się, bez nadziei na szybką poprawę, brak skuteczności w wykonywaniu ustawowo przekazanych gminie zadań publicznych zawsze wiąże się z naruszaniem Konstytucji i ustaw (por. wyrok NSA z dnia 24 listopada 2009 r., sygn. akt II OSK 1786/09, [w:] CBOSA)”.

Prakseologiczny charakter przesłanek wymienionych w art. 97 ust. 1 ustawy o samorządzie gminnym wymaga zdefiniowania przede wszystkim ocennego zwrotu „braku skuteczności” w realizacji zadań publicznych przez 
organy gminy. Oceny to wypowiedzi, w której przypisuje się pewnemu fragmentowi rzeczywistości daną wartość (dodatnią lub ujemną) (Lewandowski, 1975, s. 55-56). W nauce funkcjonuje przy tym pogląd, że do przeprowadzenia oceny funkcjonowania danej organizacji nie można stosować dowolnych ocen, a jedynie tzw. oceny praktyczne, do których zalicza oceny niewyrażające uczuć ani wzruszeń, tylko mówią o przydatności lub nieprzydatności danego czynnika biorącego udział w działaniu, a więc sprawcy, narzędzia itp. (Kotarbiński, 1975, s. 345). Skuteczność działania, jako jedna z przesłanek zawieszenia organów gminy, jest kryterium oceny zaliczanym do „walorów” sprawnego działania. Kluczowym elementem zakresu pojęciowego skuteczności jest „cenność kosztu” lub „cenność wyniku”, umożliwiająca porównywanie (w sposób dodatni lub ujemny) pożądanych i niepożądanych skutków działania. Cennością kosztów jest suma cenności wszystkich negatywnie ocenianych skutków działania. Cennością wyniku (użytecznego) jest natomiast suma wszystkich pozytywnie ocenianych skutków działania (Zieleniewski, 1976, s. 197). Jeżeli cenność celu będzie równać się cenności wyniku, wówczas działanie będzie miało walor skuteczności. W przypadku administracji publicznej pozytywnie ocenianych skutkiem działania jest przede wszystkim realizacja prawnie określonych celów i zadań publicznych, zgodnie z przepisami prawa i w formach prawem przewidzianych. Skutecznym działaniem administracji publicznej będzie zatem takie zorganizowanie administracji publicznej, które gwarantuje osiągnięcie prawnie określonych celów i zadań. Brak skuteczności w realizacji przez organy gminy zadań publicznych będzie natomiast występował w przypadku zaniechania realizacji zadań własnych lub zleconych bądź nieosiąganie wynikających z przepisów prawa rezultatów takich zadań.

Powyżej sformułowana definicja braku skuteczności nie może być jednak w sposób abstrakcyjny wykorzystywana do oceny działalności organów gminy i wartościowania tych ocen. Ocenny charakter zwrotu „brak skuteczności” sprawia, że niezbędne jest przy stosowaniu normy określonej w art. 97 ust. 1 ww. ustawy przeprowadzenie oceny „jednostkowej i sytuacyjnej”. Jak wskazuje M. Zdyb, zwroty ocenne „wymagają systematycznego dookreślania, tzn. uzyskują treściowe kontury dopiero w trakcie ustalania treści poszczególnych interesów indywidualnych, kształtowanych na bazie prawa administracyj- 
nego materialnego" (Zdyb, 1991, s. 354; Leszczyński, 2001, s. 154). Organ nadzoru, wartościując oceny skuteczności organów gminy w realizacji zadań publicznych, powinien zatem każdorazowo sprecyzować rodzaj zadań przewidzianych prawem, które nie były i nie są należycie wykonywane oraz/lub określić cele, które nie są osiągane wskutek niewykonywania lub nienależytego wykonywania zadań przez organy gminy.

Należy zaznaczyć, że hipoteza normy zawartej w art. 97 ustawy o samorządzie gminnym wskazuje na kwalifikowany brak skuteczności, tj. przedłużający się i nierokujący nadziei, jako przesłankę zawieszenia organów gminy. Organ nadzoru powinien zatem dokonać wartościowania oceny braku skuteczności, uprzednio określając stosowne mierniki. Zwrot „przedłużający się" stanowi wyznacznik, na podstawie którego organ nadzoru ustala miernik w postaci czasu trwania braku skuteczności. Przyjęty przez organ nadzoru okres powinien wypełniać generalną przesłankę naruszenia przepisów prawa poprzez np. niedotrzymywanie terminów ustawowych na rozpoczęcie i realizację zadań, bezczynność lub przewlekłość działania organów.

Kolejnym wyznacznikiem umożliwiającym wartościowanie oceny braku skuteczności jest możliwość doprowadzenia przez organy gminy do wyeliminowania stanu braku skuteczności w możliwym do przewidzenia krótkim okresie. Ustawodawca użył w tym przypadku zwrotu „nierokujący nadziei na szybką poprawę". System finansowy administracji publicznej przewiduje zasadniczo roczny okres planowania i rozliczania zadań publicznych finansowych ze środków gminy lub budżetu państwa. Można zatem przyjąć, że właściwym okresem objętym oceną przedłużającego się braku skuteczności realizacji gminy powinien być okres nie krótszy niż jeden rok. Ocena szans na „szybką poprawę” powinna natomiast uwzględniać okres maksymalnie jednego roku na doprowadzenie realizacji zadań do stanu zgodnego z prawem. W przeciwnym razie istnieje ryzyko, że organy nadzoru mogą przekroczyć zakres ingerencji nadzorczej, przyjmując, że kilkutygodniowe opóźnienie w realizacji zadań uprawnia do zawieszenia organów gminy. Niezgodne z istotą nadzoru byłoby natomiast pozbawienie organów nadzoru możliwości zawieszenia organów gminy w sytuacji przedstawienia programów naprawczych zakładających osiągnięcie stanu zgodności z prawem dopiero po kilku latach. 
Mierniki oceny „przedłużającego się” oraz „nierokującego na szybką poprawę” braku skuteczności w realizacji mogą być wyrażone liczbowo w postaci wskaźników i progów o charakterze finansowym, których przekroczenie narusza obowiązujące przepisy prawa. Analiza sprawozdań z wykonania budżetu gminy, w aspekcie osiąganych i wymaganych wskaźników i progów finansowych, pozwalaja obiektywnie ocenić bieżącą sytuację finansową gminy. Umożliwiaja również ocenić zagrożenie utrzymywania się w przyszłości stanu braku skuteczności w realizacji zadań. Miarą oceny skuteczności działań gminy może być również możliwość spłaty zobowiązań publicznoprawnych i cywilnych oraz wynikających z umów o pracę.

Należy zaznaczyć, że sformułowanie oceny, stanowiącej podstawę zawieszenia organów gminy, wymaga uprzedniej weryfikacji stanu faktycznego w zakresie realizacji zadań publicznych. Proces sprawdzenia, czy i w jakim zakresie oraz jakich terminach realizowane są zadania publiczne, nazywany jest w doktrynie ogólnym pojęciem rozliczalności administracji publicznej (Supernat, 2013, s. 35-41). Rozliczenie organów gminy z realizacji zadań publicznych dotyczy zarówno rzeczowego, jak i finansowego wykonania zadań własnych i zleconych. Rodzaj zadań, ich zakres i cele określają ustawy, sposób zaś ich realizacji ustawy bądź przepisy wykonawcze. W praktyce zakres i stopień realizacji zadań publicznych uzależniony jest od sytuacji finansowej gminy i uchwalonego budżetu gminy przez organ stanowiący, a także sprawności organizacyjnej władz gminy w realizacji zadań publicznych.

Rozliczenie władz gminy z realizacji zadań następuje poprzez weryfikacje wewnętrzną oraz zewnętrzną, przy czym brak skuteczności organów gminy zazwyczaj ujawnia kontrola zewnętrzna, przeprowadzona przez regionalną izbę obrachunkową lub Najwyższą Izbę Kontroli. Weryfikacja wewnętrzna realizowana $\mathrm{w}$ ramach kontroli zarządczej czy też audytu wewnętrznego przyczynia się wprawdzie do poprawy skuteczności działania organów gminy, np. poprzez analizę ryzyka oraz czynności kontrolne, niemniej organy nadzoru nie są zwykle informowane o wynikach takich kontroli, a w tym ujawnionych nieprawidłowościach, ze względu na obawę np. odpowiedzialności za naruszenie dyscypliny finansów publicznych przez kierownika jednostki. Organy kontroli zewnętrznej mają natomiast prawnie zabezpieczony zakres 
niezależności wobec organów gminy, umożliwiający formułowanie ocen w sposób bezstronny i obiektywny (Jagielski, 1999, s. 62 i n.).

Zawieszenie organów gminy zawsze dotyczy obu organów gminy, tj. organu wykonawczego i stanowiącego. Wynika to wprost z art. 97 ustawy o samorządzie gminny, w którym użyto zwrotów: „organy gminy” oraz „do czasu wyboru rady gminy oraz wójta”, przy zastosowaniu koniunkcji (Dolnicki, 2009, s. 415; Chmielnicki, 2004, s. 568). Rozstrzygnięcie nadzorcze wydane przez Prezesa Rady Ministrów w sprawie zawieszenia organów gminy oraz wprowadzające zarząd komisaryczny ma przy tym charakter aktu uznaniowego, którego możliwość zastosowania uwarunkowane jest od wystąpienia przesłanek określonych powyższym przepisem ustawy (Jaworska-Dębska, 2011). Ewentualne badanie legalności takiego rozstrzygnięcia ograniczone będzie zatem do ustalenia, czy zostały spełnione przesłanki formalne do zastosowania takiego aktu oraz czy nie zostały przekroczone granice uznania.

\section{Podsumowanie}

Podsumowując powyższe rozważania na temat wartościowania ocen w ramach nadzoru nad samorządem terytorialnym, należy stwierdzić, że formułowane przez organy nadzoru oceny działalności jednostek samorządu terytorialnego są poddane określonemu wartościowaniu. W zależności od wyniku tego wartościowania organ nadzoru podejmuje decyzje o zastosowaniu danego środka nadzorczego. Istotnym elementem postępowania nadzorczego jest zatem wartościowanie ocen, albowiem nie każda działalność oceniona jako nieprawidłowa, czy też niezgodna z prawem, skutkuje obowiązkiem zastosowania środka nadzoru.

Wartościowanie ocen występuje w szczególności w sytuacji rozstrzygania przez organ nadzoru stopnia naruszenia prawa (istotne lub nieistotne naruszenie, powtarzające się naruszenie Konstytucji i ustaw lub niemające takiego charakteru), a także przy ocenie działalności w realizacji zadań publicznych jako skutecznej bądź nieskutecznej.

Analiza przepisów regulujących stosowanie środków nadzorczych w postaci stwierdzenia nieważności uchwały lub zarządzenia, odwołanie organu wykonawczego oraz zawieszenia organów gminy wskazuje na konieczność posiłkowania się orzecznictwem i doktryną w procesie wartościowania ocen. 
Użycie w treści przepisów sformułowań, takich jak: istotne naruszenie prawa, przedłużający się brak skuteczności w realizacji zadań publicznych, może bowiem budzić wątpliwości interpretacyjne. Należy jednak pozytywnie ocenić, że orzecznictwo sądów administracyjnych w tym zakresie charakteryzuje się spójnością wykładni.

\section{Literatura}

Bułajewski, S. (2013). Status jednostki samorzadu terytorialnego jako akt prawa miejscowego o charakterze organizacyjno-ustrojowym, "Journal of Modern Science" $\mathrm{nr} 1 / 7$, s. 87-101. ISSN 1734-2031.

Chmielnicki, P. (2004). Nadzór nad działalnościa gminną, [w:] P. Chmielnicki (red.), Komentarz do ustawy o samorzadzie gminnym, Warszawa: Wydawnictwo Prawnicze LexisNexis, s. 568. ISBN 8373343040.

Dolnicki, B. (2009). Samorzą terytorialny, Kraków: Oficyna a Wolters Kluwer business, s. 415, ISBN 9788376014517.

Jagielski, J. (1999). Kontrola administracji publicznej, Warszawa: Wydawnictwo Prawnicze, s. 62. ISBN 8321907857.

Kamiński, M. (2011). Normatywny model przesłanek nadzorczej weryfikacji legalności aktów organów samorządowych, a granice samodzielności samorządu terytorialnego, [w:] M. Stec, M. Mączyński (red.), Nadzór nad samorządem a granice jego samodzielności, s. 45, Warszawa: Lex a Wolters Kluwer business. ISBN 9788326412608.

Lewandowski, M. (1975). Analiza struktur zadań oceniajacych, „Prakseologia” nr 3-4. ISSN 0079-4872.

Leszczyński, L. (2001). Stosowanie generalnych klauzul odsyłających, Kraków: Kantor Wydawniczy „Zakamycze”, s. 154. ISBN 8373330097.

Kotarbiński, T. (1975). Traktat o dobrej robocie, Wrocław: Zakład Narodowy im. Ossolińskich, s. 345.

Płoskonka, J. (red.). (2005). Glosariusz terminów dotyczacych kontroli i audytu w administracji publicznej, Warszawa: Najwyższa Izba Kontroli - Departament Strategii Kontrolnej, s. 25, 60-61. ISBN 8391438945, 9788391438947.

Sitek, B. (2016). Interes państwa vs. interes samorzadu lokalnego. Konflikt czy wspótpraca państwa i samorzadu?, „Journal of Modern Science”, 4/31, s. 137-138. ISSN 1734-2031. 
Sitek, M. (2017). Jakość prawa miejscowego jako warunek dobrze funkcjonujacego samorzadu, „Journal of Modern Science” 1/32, s. 154. ISSN 1734-2031.

Stahl, M. (red.), Duniewska, Z., Jaworska-Dębska, B., Michalska-Badziak, R., Olejniczak-Szałowska, E. (2002). Kontrola i nadzór nad działalnością samorządu terytorialnego, [w:] M. Stahl (red.), Prawo administracyjne. Pojęcia, instytucje, zasady $w$ teorii i orzecznictwie, s. 338, Warszawa: Difin. ISBN 8372512884.

Supernat, J. (1985). Prakseologiczne zasady nauki administracji a normy prawne. „Acta Universitatis Wratislaviensis”, No 857, „Prawo” CXLIII, Wrocław, s. 318-320.

Supernat, J., Duniewska, M. Stahl (red.). (2013). O pojęciu rozliczalności (Accountability) w administracji, [w:] Odpowiedzialność administracji i w administracji, Warszawa: WoltersKluwer, s. 35-41. ISBN 9788326444241.

Wiktorowska, A. (2002). Prawne determinanty samodzielności gminy. Zagadnienia administracyjnoprawne. Warszawa: Liber, s. 193, ISBN 8372060819.

Zieleniewski, J. (1976). Organizacja i Zarządzanie, Warszawa: Państwowe Wydawnictwo Naukowe, s. 197.

Zdyb, M. (1991). Interes jednostki w sferze luzów normatywnych (pojęcia nieostre), „Annales UMCS”, XXXVIII, s. 354.

\section{Akty prawne}

Europejska Karta Samorządu Lokalnego, sporządzona w Strasburgu dnia 15 października 1985 r. (Dz.U. z 1994 r. Nr 124, poz. 607 ze sprost.).

Konstytucja Rzeczypospolitej Polskiej z dnia 2 kwietnia 1997 r. (Dz.U. z 1997 r. Nr 78, poz. 483 ze zm. i sprost.).

Obwieszczenie Ministra Spraw Zagranicznych z dnia 22 sierpnia 2006 r. o sprostowaniu błędu (Dz.U. Nr 154, poz. 1107) (dot. zmiany tytułu na Europejską Kartę Samorządu Lokalnego).

Ustawa z dnia 8 marca 1990 r. o samorządzie gminnym (Dz.U. z 2017 r. poz. 1875).

Ustawa z dnia 23 stycznia 2009 r. o wojewodzie i administracji rządowej w województwie (Dz.U. z 2017 r. poz. 2234 ze zm.).

Ustawa z dnia 7 października 1992 r. o regionalnych izbach obrachunkowych (Dz.U. z 2016 r. poz. 561). 